\title{
Severe Rhabdomyolysis in a Pediatric Patient after Coxsackie B Virus Infection without Acute Renal Failure: A Case Report
}

Ahmad Soliman ${ }^{1}$, Supriya Bisht ${ }^{1}$, Kokila Jeyamurugan ${ }^{1}$, Palanikumar Balasundaram ${ }^{1}$, Ratna Basak

1. Pediatrics, Brookdale University Medical Center, New York City, USA

Corresponding author: Ahmad Soliman, asamsoliman@gmail.com

\begin{abstract}
Rhabdomyolysis is a condition resulting from the breakdown of skeletal muscle fibers with leakage of muscle enzymes into the circulation. The degraded muscle components in the circulation can lead to lethal complications as acute renal failure (ARF). In younger children, viral infections tend to be the major cause while trauma and exercise are the important ones in adolescents. Several viruses such as influenza A \& B, parainfluenza and coxsackie have been implicated in causing rhabdomyolysis.
\end{abstract}

We report a case of a 14-year-old girl with severe rhabdomyolysis after recent Coxsackie B infection without acute renal failure.

Categories: Pediatrics, Infectious Disease, Nephrology

Keywords: rhabdomyolysis, creatinine phosphokinase, coxsackie

\section{Introduction}

Rhabdomyolysis is a potentially life-threatening syndrome characterized by striated muscle dissolution or disintegration into the blood stream [1]. It can develop from a wide variety of causes. Viral infections are the major causes in younger children while trauma and exercise are the main etiologies in older ones. Many viruses have been reported to cause rhabdomyolysis such as influenza A/B, parainfluenza, coxsackie, Epstein-Barr (EBV), herpes simplex, adenovirus, and cytomegalovirus [2].

We report a case of a 14-year-old girl with severe rhabdomyolysis after Coxsackie B viral infection. Many studies correlate elevated levels of creatinine phosphokinase (CPK) to acute renal failure (ARF) [3-7]. However, our patient did not show any signs of ARF or deranged renal function tests despite having very high levels of serum CPK.

Received 02/16/2020 Review began 02/19/2020 Review ended 02/24/2020 Published 02/28/2020

(c) Copyright 2020

Soliman et al. This is an open access article distributed under the terms of the Creative Commons Attribution License CC-BY 4.0., which permits unrestricted use, distribution, and reproduction in any medium, provided the original author and source are credited.

\section{Case Presentation}

A previously healthy 14-year-old girl presented to the emergency department with history of passing redcolored urine for two days. She had coryza and body ache for four days. She denied abdominal pain, dysuria, recent trauma, sore throat, heavy exercise, fever, rash or any substance or drug abuse. She had taken one dose of ibuprofen 200 milligram for body ache.

On admission, her vital signs were stable. Physical examination was unremarkable except for mild tenderness over her shoulders. There was no swelling or tenderness in her lower extremities which had full range of motion. Urinalysis (UA) showed large blood and 3-5 red blood cells per high power field. CPK was reported as more than 160,000 U/L. Alanine transaminase (ALT) and aspartate transaminase (AST) were 327 $\mathrm{U} / \mathrm{L}$ and $1363 \mathrm{U} / \mathrm{L}$, respectively. Complete blood count, renal function tests, serum electrolytes (including potassium, calcium, and phosphorus), uric acid, blood gas, coagulation profile, and urine electrolytes were within normal limits. Drug abuse urine screen was negative. Acetaminophen and salicylate levels were normal. Hepatitis serology and Group A Streptococcus screen were negative. Electrocardiogram showed nonspecific ST and T wave changes (Figure 1) but echocardiogram was reported normal. EBV, Influenza A/B, Coxsackie A/B, and HIV serology were sent. 


\section{Cureus}

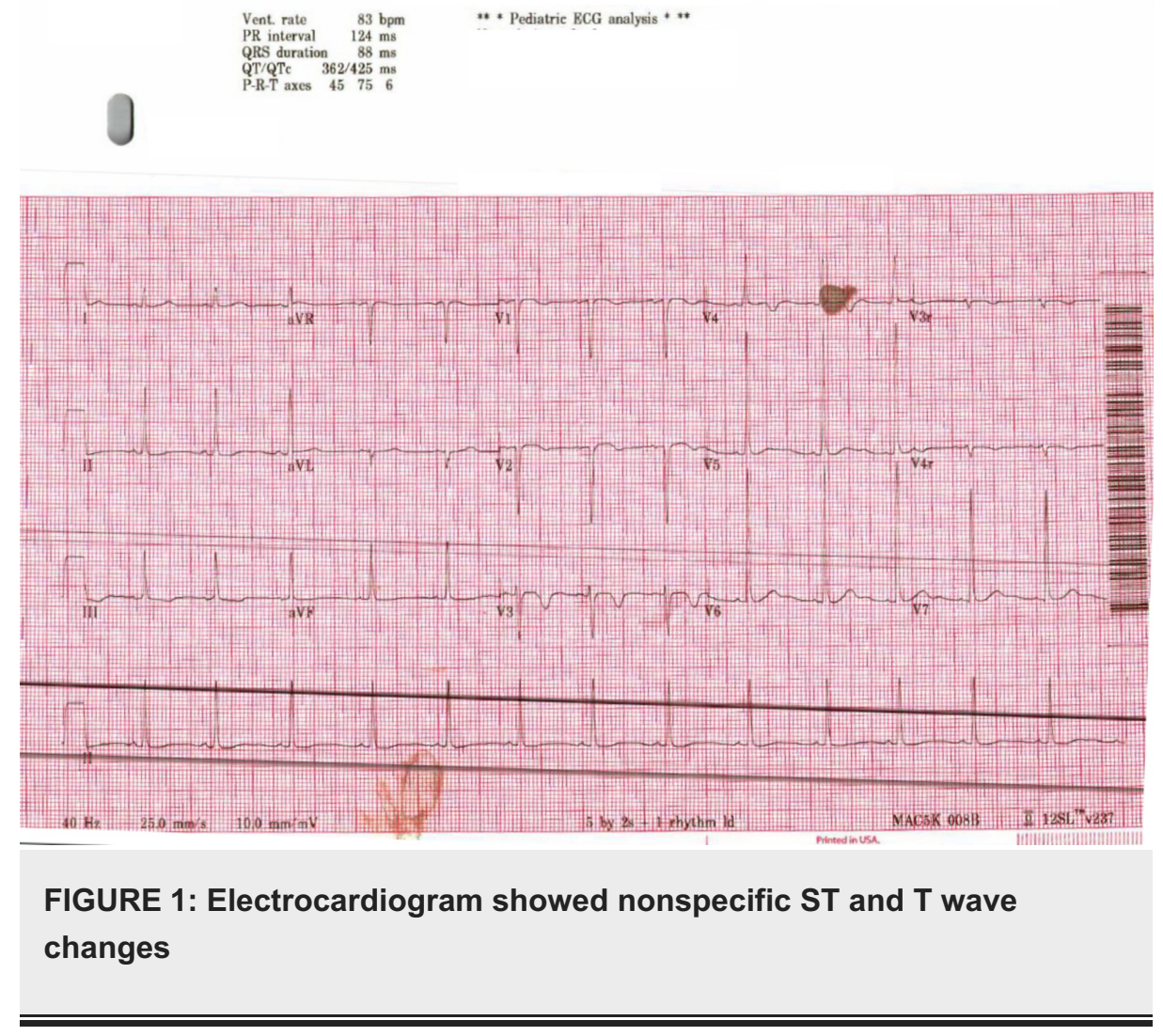

She was aggressively hydrated with two normal saline boluses in the emergency department. She was continued on two times maintenance fluids with normal saline in the inpatient floor. Bicarbonate infusion was not commenced as $\mathrm{pH}$ was 7.46 and bicarbonate level was $31.0 \mathrm{mmol} / \mathrm{L}$ in the venous blood gases. She was kept on strict input-output instructions, bed rest and was monitored for fluid overload. Repeat CPK was still more than 160,000 U/L on the second and third day of the hospital stay. They showed a declining trend on the fourth day and thereafter (Table 1, Figure 2). 


\section{Cureus}

\begin{tabular}{|c|c|c|c|c|c|}
\hline & $\begin{array}{l}\text { Creatinine } \\
\text { Phosphokinase (CPK) } \\
\text { (Ref:30-135 U/L) }\end{array}$ & $\begin{array}{l}\text { Blood Urea Nitrogen } \\
\text { (BUN) (Ref: 0.5-17 } \\
\mathrm{mg} / \mathrm{dL} \text { ) }\end{array}$ & $\begin{array}{l}\text { Serum Creatinine } \\
\text { (Ref: } 0.52-1.04 \\
\mathrm{mg} / \mathrm{dL} \text { ) }\end{array}$ & $\begin{array}{l}\text { Serum Alanine } \\
\text { Transaminase (ALT) } \\
\text { (Ref: 9-52 U/L) }\end{array}$ & $\begin{array}{l}\text { Serum Aspartate } \\
\text { Aminotransferase (AST) } \\
\text { (Ref: 14-36 U/L) }\end{array}$ \\
\hline $\begin{array}{l}\text { 1st } \\
\text { day }\end{array}$ & $>160,000$ & 11 & 0.84 & 327 & 1363 \\
\hline $\begin{array}{l}2 \text { nd } \\
\text { day }\end{array}$ & $>160,000$ & 3 & 0.47 & 368 & 1408 \\
\hline $\begin{array}{l}3 \text { rd } \\
\text { day }\end{array}$ & $>160,000$ & 4 & 0.45 & 532 & 1408 \\
\hline $\begin{array}{l}\text { 4th } \\
\text { daay }\end{array}$ & 133,626 & 4 & 0.44 & 510 & 864 \\
\hline $\begin{array}{l}\text { 6th } \\
\text { day }\end{array}$ & 61,382 & & & & \\
\hline $\begin{array}{l}7 \text { th } \\
\text { daay }\end{array}$ & 47,012 & 5 & 0.38 & 390 & 389 \\
\hline $\begin{array}{l}\text { 8th } \\
\text { day }\end{array}$ & 28,591 & & & & \\
\hline $\begin{array}{l}\text { 9th } \\
\text { day }\end{array}$ & 22,165 & & & & \\
\hline $\begin{array}{l}\text { 10th } \\
\text { day }\end{array}$ & 11,674 & 4 & 0.4 & & \\
\hline
\end{tabular}

TABLE 1: Laboratory values of creatinine phosphokinase (CPK), blood urea nitrogen (BUN), serum creatinine, serum alanine transaminase (ALT), serum aspartate aminotransferase (AST) during the hospital stay

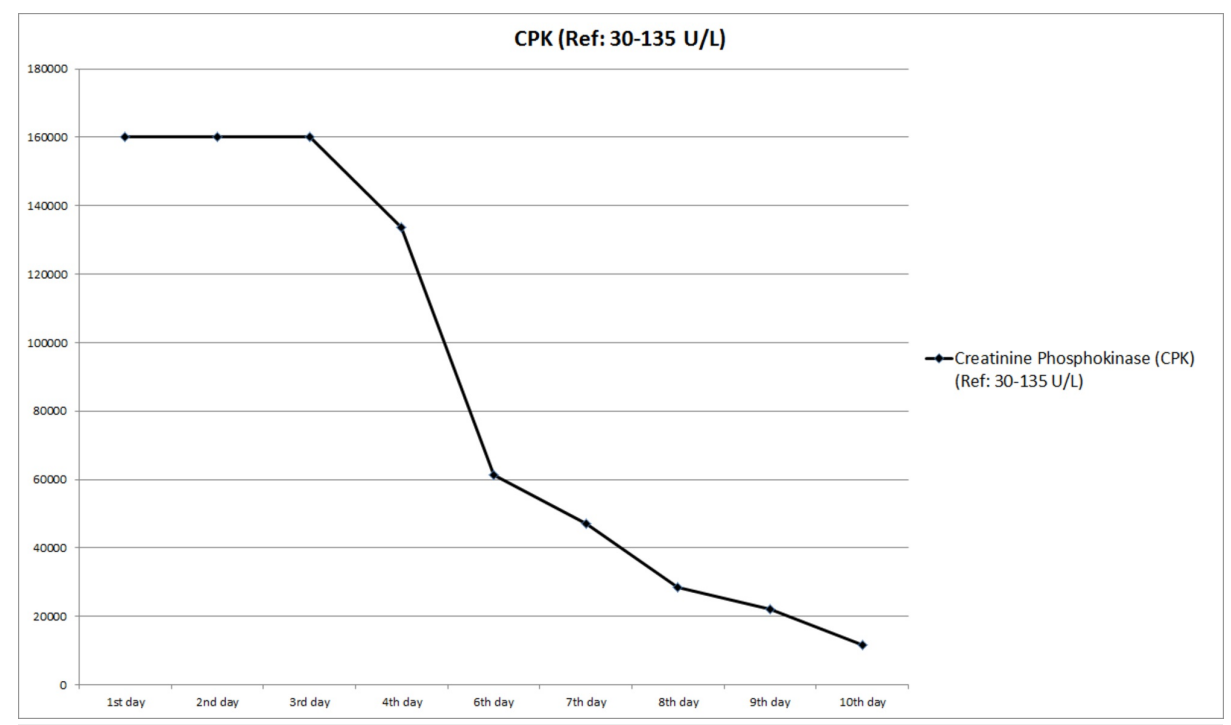

FIGURE 2: Trend of creatinine phosphokinase (CPK) values during the hospital stay

ALT and AST levels trended down (Table 1). Renal function tests remained normal throughout (Figure 3). 


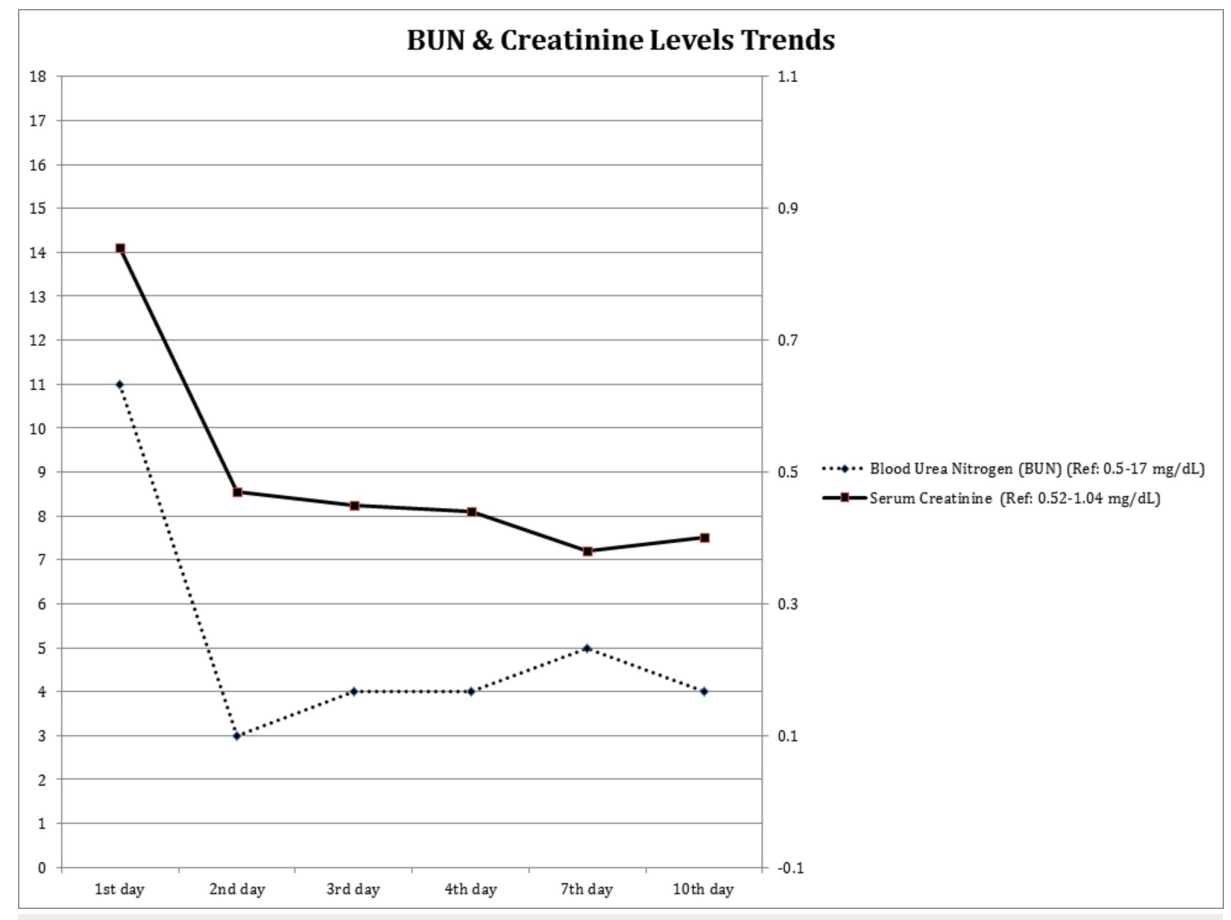

FIGURE 3: Trends of renal function tests during the hospital stay

Serum ammonia, lactate, pyruvate and plasma acylcarnitine, which were drawn to rule out the other etiologies, were negative. Coxsackie B antibodies were positive (B1, B5, and B6 were 1: 64, while B2, B3, and B4 were 1: 32 positive), while the Coxsackie A antibodies were negative.

On the tenth day, CPK trended down to $11674 \mathrm{U} / \mathrm{l}$, parenteral fluids were weaned down and oral fluid intake was encouraged. She was discharged on the following day. One week later, she was followed up in the outpatient department and her blood test results were back to normal.

\section{Discussion}

Rhabdomyolysis is a syndrome of muscle necrosis and release of muscle components in the circulation and urine. Most of the literature on rhabdomyolysis is drawn from adult studies. The data on pediatric rhabdomyolysis is very limited [2].

The most common causes of rhabdomyolysis in adults are muscular trauma and exogenous toxins $[7,8]$. Trauma is the most common etiology in older children [2]. In young children under nine years, viral infection is the most common cause [2]. Viruses may cause rhabdomyolysis by directly attacking the muscle and generating muscle-specific toxin. Influenza A\&B and enteroviruses (Coxsackie A\&B) were found to be the most common etiology $[2,9,10]$. Other viral agents that were reported to cause viral myositis or rhabdomyolysis include Epstein-Barr virus (EBV), human immunodeficiency virus (HIV), and herpes simplex virus [11-13].

Coxsackie B is a group of six serotypes of coxsackievirus which are under enteroviruses. They can present from being asymptomatic to causing severe myalgia and muscle pain. Initial symptoms may be non-specific symptoms such as fever, malaise, headache, and gastrointestinal upset. They may also cause severe chest and muscle pain known as pleurodynia. They account for $50-90 \%$ of aseptic meningitis cases.

Our patient had mild non-specific symptoms like malaise, headache, and rhinorrhea for two days before passing red-colored urine with very high serum CPK levels. Although many studies correlate elevated levels of CPK to ARF, our patient did not show any signs of ARF or deranged renal function tests [3-7]. This is the first instance reported in the literature where such high CPK levels in a pediatric patient with Coxsackie B rhabdomyolysis, did not lead to ARF.

\section{Conclusions}

Viral-induced myositis appears to be the most common etiology for rhabdomyolysis in younger children. Among viral infections, influenza $A \& B$ and enteroviruses (Coxsackie $A \& B$ ) were found to be the most common etiologies. Absence of ARF in a pediatric patient with Coxsackie B rhabdomyolysis and such high $\mathrm{CPK}$ levels, is not reported in the literature previously. Testing for viruses including Coxsackie A or B should 
be considered while investigating a child with severe non-traumatic rhabdomyolysis.

\section{Additional Information \\ Disclosures}

Human subjects: Consent was obtained by all participants in this study. Conflicts of interest: In compliance with the ICMJE uniform disclosure form, all authors declare the following: Payment/services info: All authors have declared that no financial support was received from any organization for the submitted work. Financial relationships: All authors have declared that they have no financial relationships at present or within the previous three years with any organizations that might have an interest in the submitted work. Other relationships: All authors have declared that there are no other relationships or activities that could appear to have influenced the submitted work.

\section{References}

1. Sauret JM, Marinides G, Wang GK: Rhabdomyolysis. Am Fam Physician. 2002, 65:907-913.

2. Mannix R, Tan ML, Wright R, Baskin M: Acute pediatric rhabdomyolysis: causes and rates of renal failure . Pediatrics. 2006, 118:2119-2125. 10.1542/peds.2006-1352

3. Talving P, Karamanos E, Skiada D, et al.: Relationship of creatine kinase elevation and acute kidney injury in pediatric trauma patients. J Trauma Acute Care Surg. 2013, 74:912-916. 10.1097/TA.0b013e318278954e

4. Bhavsar P, Rathod KJ, Rathod D, Chamania CS: Utility of serum creatinine, creatine kinase and urinary myoglobin in detecting acute renal failure due to rhabdomyolysis in trauma and electrical burns patients. Indian J Surg. 2013, 75:17-21. 10.1007/s12262-012-0451-6

5. Brancaccio P, Lippi G, Maffulli N: Biochemical markers of muscular damage. Clin Chem Lab Med. 2010, 48:757-767. 10.1515/CCLM.2010.179

6. Melli G, Chaudhry V, Cornblath DR: Rhabdomyolysis: an evaluation of 475 hospitalized patients . Medicine (Baltimore). 2005, 84:377-385.

7. Bosch X, Poch E, Grau JM: Rhabdomyolysis and acute kidney injury. N Engl J Med. 2009, 361:62-72. 10.1056/NEJMra0801327

8. Huerta-Alardín AL, Varon J, Marik PE: Bench-to-bedside review: rhabdomyolysis -- an overview for clinicians. Crit Care. 2004, 9:158. 10.1186/cc2978

9. Fodili F, van Bommel EF: Severe rhabdomyolysis and acute renal failure following recent Coxsackie B virus infection. Neth J Med. 2003, 61:177.

10. Crum-Cianflone NF: Bacterial, fungal, parasitic, and viral myositis. Clin Microbiol Rev. 2008, 21:473. 10.1128/CMR.00001-08

11. Roychowdhury N, Shivakumar A, Mustafa N, Patil R, Salahuddin N: A rare cause of rhabdomyolysis . South Med J. 2007, 100:333-334. 10.1097/SMJ.0b013e318030f082

12. Same RG, McAleese S, Agwu AL, Arav-Boger R: Acute HIV in an adolescent male with fever and rhabdomyolysis. J Adolesc Health. 2019, 65:567-569. 10.1016/j.jadohealth.2019.05.021

13. Shanmugam S, Seetharaman M: Viral rhabdomyolysis. South Med J. 2008, 101:1271-1272. 10.1097/SMJ.0b013e318183649a 